Gut, 1982, 23, 247-249

\title{
Herpesvirus colitis: a new cause of diarrhoea in a patient with Hodgkin's disease
}

\author{
A J M BOUlTON, D N SLATER, * AND B W HANCOCK \\ From the Departments of Medicine and Pathology, Royal Hallamshire Hospital, Sheffield
}

SUMMARY A 57 year old woman developed severe diarrhoea during chemotherapy for Hodgkin's lymphoma. Extensive colonic ulceration was observed at necropsy and electron microscopy showed intranuclear virions consistent with herpesvirus infection. Antibody titres and immunoperoxidase studies indicated that the virus was probably herpes simplex.

Herpesvirus infection is a well-recognised complication in patients with lymphoma. ${ }^{1}$ Although upper gastrointestinal involvement by herpes simplex virus has been described, ${ }^{2} 3$ it has not been previously reported as a cause of colitis. We describe a patient with Hodgkin's disease and severe diarrhoea in whom necropsy showed the presence of colitis. Investigations showed that this was probably due to herpes simplex virus.

\section{Case report}

A 57 year old Caucasian woman presented in October 1979 with a two month history of diarrhoea and weight loss. Clinical examination and investigations, including sigmoidoscopy, stool culture, full blood count, and barium enema were normal. Rectal biopsy showed mild non-specific inflammatory changes. Splenomegaly was detected in December 1979 and further investigations including barium meal and follow through, jejunal biopsy, serum proteins, iron, folate, $B_{12}$, and immunoglobulins were normal. However, gall stones were detected on an ultrasound scan and a cholecystectomy was performed, At operation, enlarged abdominal lyph nodes were seen and consequently liver, spleen, and lymph node biopsies were performed. Histology showed mixed cell Hodgkin's disease (stage IV). Chemotherapy with mustine, vincristine, procarbazine, and prednisolone was started in February 1980. Six weeks later she

*Address for correspondence: Dr D Slater, Floor E, Histopathology, Medical School, Beech Hill Road, Sheffield S10 2RX.

Received for publication 10 August 1981 complained of anorexia, lethargy, and confusion and examination revealed a temperature of $39.5^{\circ} \mathrm{C}$. Culture of blood, urine, sputum, and cerebrospinal fluid was sterile. Complement fixation tests showed a titre of antibodies against herpes simplex virus of 1 in 80 and against cytomegalovirus of 1 in 20; no rise in either titre was observed over a two week period. Antibodies against other members of the herpes virus group including varicella zoster and Epstein-Barr virus were not detected. In view of her continuing pyrexia and low white cell count $\left(2 \cdot 1 \times 10^{9} / 1\left(2100 / \mathrm{mm}^{3}\right)\right)$ empirical treatment with gentamicin, cephradine, and hydrocortisone was started.

Although a temporary clinical improvement was observed, severe watery diarrhoea developed. A partial response was observed to loperamide, but despite transfusion and further broad spectrum antibodies her condition deteriorated and she died three weeks later.

At necropsy there was no evidence of residual lymphoma. The entire large intestine showed numerous well-defined irregular ulcers varying in size between 0.1 and $2 \mathrm{~cm}$ (Fig. 1). Histological examination showed full thickness mucosal ulceration with a mixed inflammatory cell infiltrate and multinucleate giant cell formation in the epithelium adjacent to the ulcers (Fig. 2). The appearances were not those of lymphomatous infiltration, pseudomembranous, Crohn's, ulcerative, or ischaemic colitis. The remainder of the upper gastrointestinal tract was normal. Each kidney showed a $0.5 \mathrm{~cm}$ yellow area in the cortex which histologically was found to be a focus of parenchymal necrosis with multinucleate giant cell formation in the tubular epithelium. Viral inclusion 




Fig. 1 Colonic ulcers observed at necropsy.

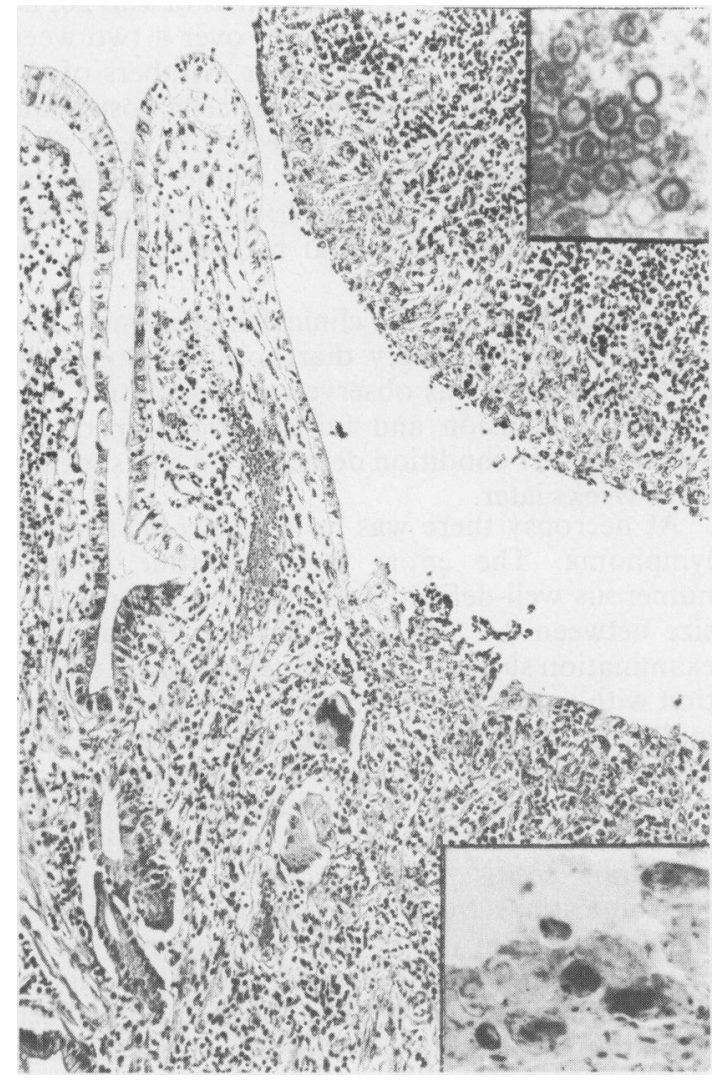

Fig. 2 Ulcer with a multinucleate giant cell near the edge. Haematoxylin and eosin, $\times 70$ (original magnification). Upper inset: herpesvirus virions. $\times 75000$. Lower inset: peroxidase anti-peroxidase technique with rabbit anti-herpes simplex virus. Positively staining cells are seen in the ulcer base. $\times 160$ (original magnification).

bodies were not seen. Culture of the necrotic renal tissue and large bowel mucosa failed to grow any significant bacterial or fungal pathogen. Clostridium difficile toxin was not isolated. Serum obtained at necropsy (interval from death to necropsy was four hours) was submitted for viral studies. Complement fixation tests showed a titre of antibodies against herpes simplex virus of 1 in 320 and against cytomegalovirus of 1 in 20. One antemortem and the postmorten serum sample were also submitted for immunofluorescence antibody tests against herpes simplex virus types 1 and 2; antibodies were found against types 1 and 2 at titres of 1 in 100 and 1 in 500 respectively in the antemortem sample and titres of 1 in 250 and 1 in 2000 in the postmortem sample. Tissue from the large bowel and kidney was examined by transmission electron microscopy and scattered cytoplasmic and intranuclear $130 \mathrm{~mm}$ virions (Fig. 2-upper inset) consistent with herpesvirus were identified. Using standard peroxidase rabbit antiperoxidase (PAP) techniques and appropriate controls ${ }^{4}$ on paraffin sections of the colon, rabbit 
anti-herpes simplex virus demonstrated brown cytoplasmic and nuclear deposits in degenerate epithelial cells of the colonic ulcers. The PAP technique with human anti-cytomegalovirus and prior blocking of endogenous human immunoglobin failed to demonstrate such deposits.

\section{Discussion}

An increased incidence of visceral herpes simplex virus infection is well recognised in patients with lymphoma and other malignancies. ${ }^{1}$ In a review of 6694 necropsies, Rosen and Hajdu ${ }^{5}$ found 31 such cases, with oesophageal infection in 25 . Cytomegalovirus, another of the herpesvirus group, has also been shown to cause infection in the upper gastrointestinal tract of immunosuppressed patients. ${ }^{6}$ Herpes simplex virus has been isolated from the ileum of an immunosuppressed patient who experienced severe diarrhoea terminally. ${ }^{3}$ Rectal involvement has also been described in homosexual males, ${ }^{7}$ but characteristically presents as constipation. ${ }^{8}$

We consider that the patient's episode of terminal diarrhoea was probably due to herpes simplex virus colitis. The naked eye and microscopical appearance of the colonic ulcers was considered to be highly unusual and not that of more common causes of diarrhoea. Electron microscopy demonstrated virions consistent with the herpesvirus group and immunoperoxidase and serum antibody investigations were highly suggestive of the virus being herpes simplex virus. Although necropsy blood is not ideal for antibody studies, in this case there was a very short interval from death to necropsy. The apparent rise in antibody titres during the terminal illness is therefore probably both meaningful and significant. Relatively high titres of herpes simplex virus antibodies were also present before the terminal disease and may be considered consistent with chronic herpes simplex virus infection. It is there- fore possible that this virus was the cause of the patient's initial episode of diarrhoea and it has been suggested that immunosuppressive therapy may be a factor in triggering the systemic spread of herpes simplex virus, ${ }^{3}$ as occurred in our patient.

Immunosuppressed patients with widespread infection with this virus, usually have mucocutaneous manifestations, ${ }^{39}$ but such lesions were not observed in our patient.

Because of antigenic overlap between herpes simplex virus types 1 and 2 , differentiation between the two types is difficult. However, the immunofluorescent antibody tests in this case, indicated that the virus was possibly type 2 .

Herpesvirus colitis should be considered in the differential diagnosis of diarrhoea in patients with lymphoma and those of immunosuppressive therapy.

\section{References}

1 Casazza AR, Duvall CP, Carbone PP. Infection in lymphoma. JAMA 1966; 197:710-6.

2 Howiler W, Goldberg HI. Gastroesophageal involvement in herpes simplex. Gastroenterology 1976; 70:775-8.

3 Montgomerie JZ, Becroft DMO, Croxson MC, Doak PB, North JDK. Herpes simplex virus infection after renal transplantation. Lancet 1969; 2:867-71.

4 Heyderman E. Immunoperoxidase technique in histopathology: Applications, methods and controls. J Clin Pathol 1979; 32:971-8.

5 Rosen P, Hajdu SI. Visceral herpes virus infections in patients with cancer. Am J Clin Pathol 1971; 56:459-65.

6 Franzin G, Novelli P, Fratton A. Histologic evidence of cytomegalovirus in the duodenal and gastric mucosa of patients with renal allograft. Endoscopy 1980; 12:117-20.

7 Goldmeier D. Proctitis and herpes simplex virus in homosexual men. Br J Vener Dis 1980; 56:111-4.

8 Goldmeier D, Bateman JRM, Rodin P. Urinary retention and intestinal obstruction associated with ano-rectal herpes simplex virus infection. $\mathrm{Br} \mathrm{Med} J$ 1975; 2:425-6.

9 Muller SA, Herrman EC, Winkelmann RK. Herpes simplex infection in haematologic malignancies. Am JMed 1972; 52:102-14. 